Vietnam Academy of Science and Technology
Vietnam Journal of Earth Sciences
http://www.vjs.ac.vn/index.php/jse

\title{
A Digital Shoreline Analysis System (DSAS) applied on mangrove shoreline changes along the Giao Thuy Coastal area (Nam Dinh, Vietnam) during 2005-2014
}

\author{
Nguyen An Thinh'* Luc Hens² \\ ${ }^{1}$ Hanoi University of Natural Resources and Environment (HUNRE), Vietnam \\ ${ }^{2}$ Flemish Institute for Technological Research (VITO), Belgium
}

Received 10 November 2016. Accepted 12 February 2017

\begin{abstract}
The paper deals with a combination of the Digital Shoreline Analysis System (DSAS) and remote sensing, studying historical mangrove shoreline changes and mangrove zoning in the Giao Thuy coastal area of the Nam Dinh province, Vietnam. The results show an over-all mangrove area increase of 2,487 hectares during the years 2005-2014. This dynamics results from both degradation and increase of the mangroves. The calculated degradation rate is 1.41 $\mathrm{m} \mathrm{yr}^{-1}$, and the growth rate is $1.26 \mathrm{~m} \mathrm{yr}^{-1}$ on average. 4 different mangrove zones were delineated based on the End Point Rate (EPR) values of DSAS transects. The differential evolution of the mangroves in these zones is driven by socio-economic and environmental factors. The results contribute to practices of mangrove planning and management in a coastal area. Furthermore, historical mangrove shoreline change provides indicators to monitor coastal environmental changes for global warming, climate change, storm effects, sea level change, pollution, and sedimentation rates.
\end{abstract}

Keywords: Digital Shoreline Analysis System (DSAS), mangrove shoreline changes, mangrove zoning, transect, Giao Thuy coast, Vietnam.

C2017 Vietnam Academy of Science and Technology

\section{Introduction}

Mangroves provide a variety of beneficial ecosystem services such as protecting shorelines, accelerating sediment accretions, and buffering shorelines from erosion by storms and waves (Sathirathai and Barbier, 2001). Combinations of both natural and human driving forces cause significant mangrove changes

*Corresponding author, Email: anthinhhus@gmail.com along the coasts. Considerable natural driving forces include storm damage, and changes in rainfall, tidal regimes and sea level (Ellison, 2000; Lewis, 2005); whereas, urbanization, industrialization, and aquaculture are considered main human contributing factors to mangrove changes (Cohen and Lara, 2003; Rebelo et al., 2009; Tran et al., 2014). The reconstruction of mangrove changes allows identifying historical coastline dynamics, assessing the intensity and impact of natural hazards 
Nguyen An Thinh and Luc Hens/Vietnam Journal of Earth Sciences 39 (2017)

and developments in coastal areas, among others in the context of global climate change (Alongi, 2008). Traditionally, remote sensing and GIS were recommended to detect and describe mangrove changes. To this end, both aerial photos and satellite images were used. More recently the combination of remote sensing and GIS with spatial models as fractal analysis (Nguyen et al., 2015) or Digital Shoreline Analysis System (DSAS) (Thieler et al., 2009) was used. Because DSAS is effective for calculating changing rates of mangrove boundary changes incorporating an evidently -identified attribute position at separate times (Cohen and Lara, 2003; Sheik and Chandrasekar, 2011), it is able to provide a better understanding of the nature, dynamics and trend of mangrove shoreline change.

DSAS applications to study shoreline dynamics in coastal areas are found in the USA, Turkey, Italy, Cameroon, Ghana, India, Bangladesh, and Vietnam - just listing these examples (Moussaid et al., 2015; Hegde and Akshaya, 2015). Vietnamese research using DSAS showed shoreline changes in the Nam Dinh coast (To and Thao, 2008), Kien Giang coast (Nguyen et al., 2015), and in the MuiCa Mau coast, where long-term changes were documented (Tran et al., 2014). To and Thao (2008) indicates that the shoreline moved forward 37-39 meters in Xuan Thuy coast during 1905-1992; whereas, Nguyen et al., 2015 show that mangrove extent in Kien Giang coast decreased during period 19891992, increased during 1992-2003, and decreased during 2003-2006.

The GiaoThuy district has a volatile economy on the move, in particular in its central area and along the coast. The largest, partially protected mangrove area of the Red River Biosphere Reserve (BR), is found in the Xuan Thuy National Park (NP) along the coast of Giao Thuy. Tidal alluvial soil covers the area, which facilitates the growth of the mangrove forest ( $\mathrm{Vu}, 2016)$. Mangroves in this area changed significantly over last centuries (Pham and Nguyen, 2016); their surface in- creased since the last ten years. However, urbanization, agro-aquaculture, and marine infrastructure construction recently caused mangrove degradation in specific locations. Moreover, climate change hazards as storms, floods, and sea level rise synergistically contribute to the degradation. To counteract this degradation, strategic spatial planning targeted at sustainable mangrove management, and addressing the conflicts between mangrove protection and socio-economic development is most necessary.

This paper aims at zoning the mangroves along the coast of Giao Thuy based on mangrove shoreline changes during the period 2005-2014. Rates of mangrove shoreline degradation and increaseare calculated using DSAS data derived from LANDSAT satellite images.

\section{Material and methods}

\subsection{Study area}

The coastline of GiaoThuy is 32 kilometers long and stretches along the northeast of the Nam Dinh province (Figure 1). The coastal communes are Giao Thien, Giao An, Giao Lac, Giao Xuan, Giao Hai, Giao Long, Bach Long, Giao Phong, and Quat Lam. As part of the Red River Delta, this area has two estuaries - Ba Lat and Day- where most mangroves are found. Xuan Thuy NP which is located in the south of the Ba Lat estuary, is planned as the core area of the Red River BR. This is the first RAMSAR site in Southeast Asia since the Convention took effect in 1989. Most mangroves in Giao Thuy are found in the Xuan Thuy NP and in the Ba Lat estuary. Almost all the mangrove trees were planted which explains the occurrence of Kandeliaobovata as the dominant species. The most spread species mixtures consist of Aegicerascorniculatum + Sonneratiacaseolaris + Avicennia marina + Acanthus ilicifolius, 
Kandeliaobovata + Aegicerascorniculatum (in Xuan Thuy NP), and of Aegicerascorniculatum + Avicennia marina (in Con Lu area), and Kandeliaobovata (in the Giao Lam com- mune). The study period 2005-2014 was selected because of the strong economic growth in the district, which affected considerably mangrove changes along the coast.

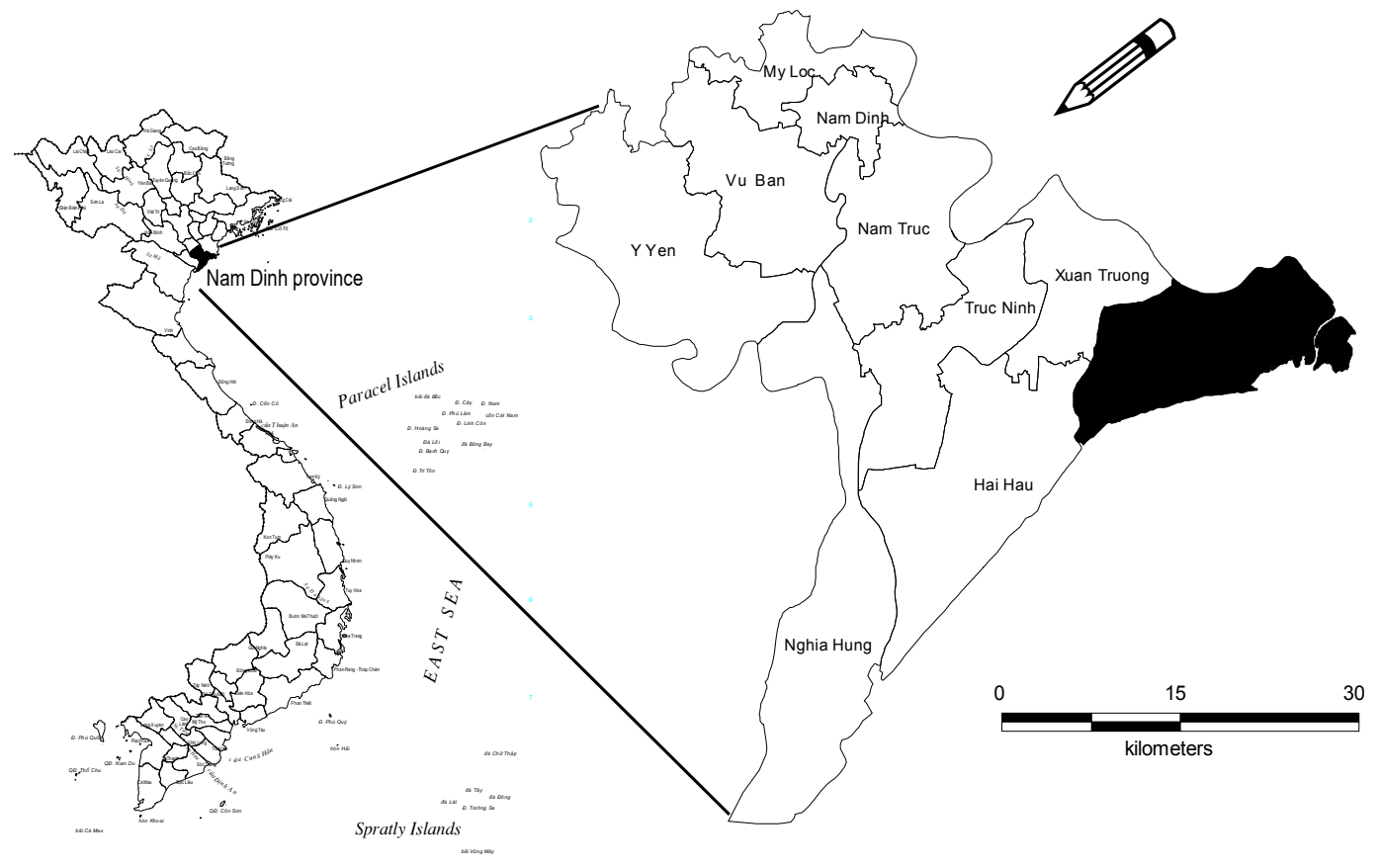

Figure 1. The location of the Giao Thuy district in the Nam Dinh province

\subsection{Satellite detection of mangroves}

Available remotely sensed images were used as the primary data to detect mangrove covers. Three LANDSAT TM satellite images (table 1), realized respectively on 2005 Oct 10 and 2010 Nov 9 (LANDSAT 7 ETM+), and 2014 Sep 25 (LANDSAT 8 OLI-TIRS) were used. Although the Nam Dinh province, is well covered by good spatial data (aerial photos from 1942, Corona (American highresolution images from 1960-1963), SPOT4 and 5, and IKONOS-images), these LANDSATdata sources are sufficient to describe major changes in mangrove cover over the province. Recently, Nguyen et al., 2015 used Landsat images to map mangrove in the Kien Giang coastal area, Vietnam. The results showed that Landsat images are able to fit for mapping mangrove in such areas because they are cloud free and freely available. The LANDSAT data were downloaded for free from the United States Geological Survey (USGS) homepages (http://earthexplorer.usgs.gov). Using the ENVI® system version 5.2 (the Environment for Visualizing Images, USA), satellite images were submitted to the supervised classification. Bare tidal soil (BS), water (WA) and five land cover types were recognized on the satellite images: built-up land (BU), cropland (CR), marshland (ML), salt production areas (SP), and mangroves (MA). Salt production areas (SP) was principally recognized by its extent and location: this type of land cover locates limitedly in costs of Bach Long, Giao Phong, and Quat Lam. Two land cover transition matrices allowed describing areas where 
mangroves changed to another type of land cover and vice versa during the periods 20052010 and 2010-2014. For each land cover type, the evolution of its surface during the study period was calculated using class statis- tics, post classification in an ENVI environment. Because the LANDSAT image specifies the pixel size in its header, the resulting class statistics include the area covered by each selected class (land cover type).

Table 1.Characteristics of LANDSAT TM satellite images

\begin{tabular}{llccc}
\hline $\begin{array}{c}\text { Bands and } \\
\text { wavelength }(\mu \mathrm{m})\end{array}$ & $\begin{array}{c}\text { Spatial resolution } \\
\text { (meters) }\end{array}$ & $\begin{array}{c}\text { Swathwidth } \\
\text { (kilometers) }\end{array}$ & $\begin{array}{c}\text { Repeatcoverage } \\
\text { (days) }\end{array}$ & $\begin{array}{c}\text { Orbitaltitude } \\
(\text { kilometers })\end{array}$ \\
\cline { 1 - 3 } $1(0.45-0.52)$ & 30 & 185 & 16 & 705 \\
$2(0.52-0.60)$ & 30 & 185 & 16 & 705 \\
$3(0.63-0.69)$ & 30 & 185 & 16 & 705 \\
$4(0.76-0.90)$ & 30 & 185 & 16 & 705 \\
$5(1.55-1.75)$ & 30 & 185 & 16 & 705 \\
$6(10.40-12.50)$ & 120 & 185 & 16 & 705 \\
$7(2.08-2.35)$ & 30 & 185 & & 705 \\
\hline
\end{tabular}

\subsection{Digital Shoreline Analysis System (DSAS)}

The Digital Shoreline Analysis System (DSAS) is a GIS-based system developed by the United States Geological Survey (USGS). Two DSAS versions are available: the DSAS extension of the Environmental System Research Institute (ESRI)'s ArcGIS software (Thieler et al., 2009), and the DSAS web. The DSAS software was selected because it runs faster than the web-based version. DSAS measures gaps between the shoreline positions during defined periods of time. This provides the basic data to calculate the shoreline changes. The historical trend of these shoreline changes is based on indicators of the shoreline geometry. The system controls the following coastline characteristics: historical coastline dynamics, shoreline change, development and evolution of gulls, cliff retreat and erosion, shoreline measurement and modeling (Oyedotun, 2014). In this study, the End Point Rate (EPR) was chosen the statistical parameters describing the spatial patterns of shoreline change (Thieler et al., 2009). EPR measures mangrove shoreline change by dividing the distance of the mangrove shoreline between its initial (year 2005) and the most recent position of shoreline (year 2014).

Figure 2 shows the DSAS components and its operational flow. DSAS components include the baselines (the starting points of all transects), historical shorelines (for the studied periods), DSAS transects (casting from the baseline and intersect the multiple shoreline features), measurement points, measurement distances, and shoreline uncertainty (setup as a Personal Geodatabase in DSAS). Baseline, historical shorelines, and shorelines uncertainty are input data provided by the mangrove cover maps of 2005, 2010, and 2015. The spacing between transects along the baseline and the length of transects were defined based on the mangrove pattern. The distance between two neighboring transects is 100 meters. DSAS transects are 2,000 meters long. With a coastline of 32 kilometers, the maximum number of DSAS transects is 320 . However, the Giao Long and GiaoHai communes have no mangroves: consequently only 272 DSAS transects were defined. The DSAS operational flow includes 4 steps: (i) Set default parameters (step 1): Establish transects, shoreline calculations, metadata and $\log$ file output options; (ii) Cast transects (step 2): establish a transect geodatabase, a casting method by using smoothing distances, flip baseline orientation, and a transect metadata file; (iii) Edit (step 3):modify the baseline and directly edit individual transects; (iv) Calculate the change statistics (step 4): including process data (choose existing transect layers, select the statistics to be calculated, specify the confidence 
intervals, and shoreline intersection thresholds), validate, and extract the outputs (define measurement locations and the external module XML input table).

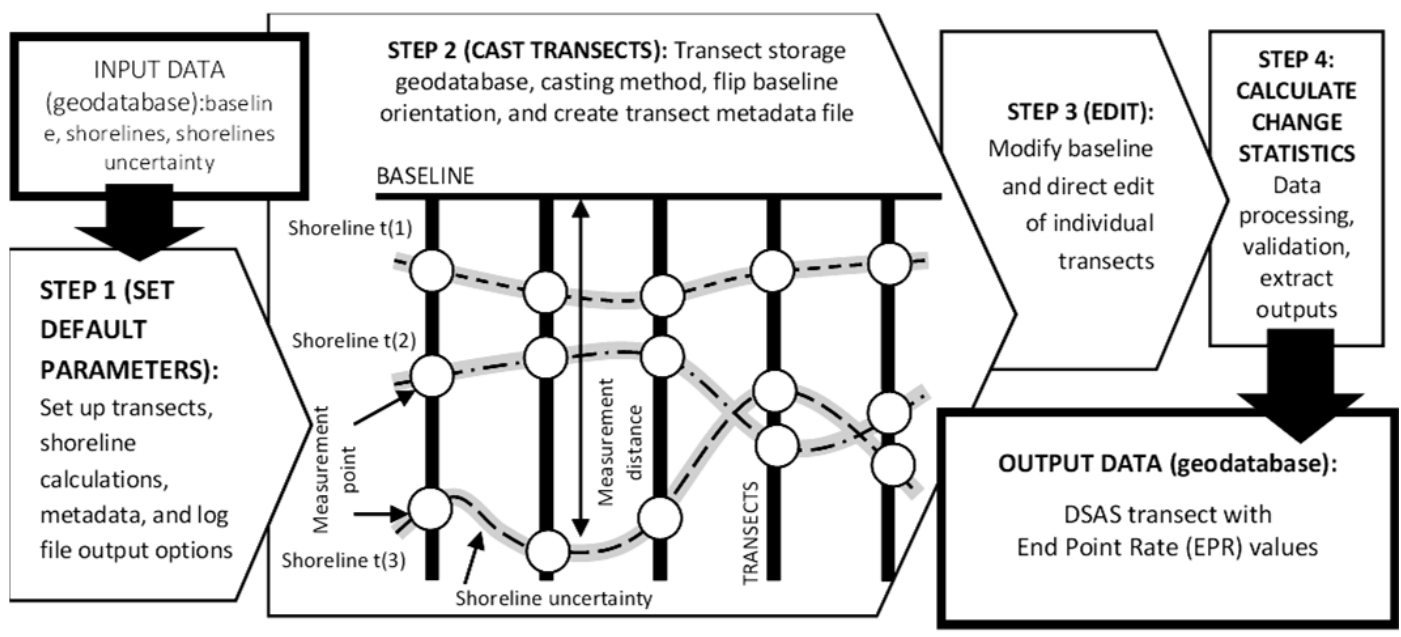

Figure 2. Digital Shoreline Analysis System components and operational flows

\section{Results}

\subsection{Reconstruction of mangrove cover change}

Three mangrove cover maps extracted from LANDSAT satellite images show that the mangrove area increased faster and faster during the period 2005-2014. By 2014 mangroves were found in 7 of the 9 coastal communes along the $\mathrm{Ba}$ Lat and Day estuaries: Giao Thien, Giao An, Giao Lac, Giao Xuan (Ba Lat estuary), Bach Long, Giao Phong, and Quat Lam (Day estuary). Mangroves increased by 2,487 hectares over a period of 10 years, which corresponds with an average ex-

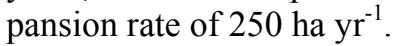

In 2005 the mangroves covered 1,387 hectares; by 2010 the figure increased to 2,309 hectares. This corresponds with an increase of 9,212 hectares. During this first period the mangrove cover changed gradually driven by agro-aquaculture, afforestation and ecological succession. $\mathrm{CR}$ and $\mathrm{BS}$ were the main land cover types which turned into MA: 380 hectares of CR and 671 hectares of BS were involved. During the same period, MA mainly changed to 110 hectares of CR and 49 hectares of BS.

Mangrove change during 2010-2014 shows similar trends as during the previous period. In 2014 there were 3,874 hectares of mangroves, which corresponds with an increase of 1,565 hectares over 5 years. The changes are explained by urbanization, agro-aquaculture and afforestation. 163 hectares of CR and 1,903 hectares of BS were the main land cover types which were transformed in mangroves. Mangroves also changed in $\mathrm{CR}, \mathrm{BU}$ and BS $(369,85$, and 44 hectares respectively). Figure 3 shows limited changes in mangrove cover in the Day estuary, while their expansion and defragmentation was most significant in the Xuan Thuy NP and the Ba Lat estuary. 
Nguyen An Thinh and Luc Hens/Vietnam Journal of Earth Sciences 39 (2017)
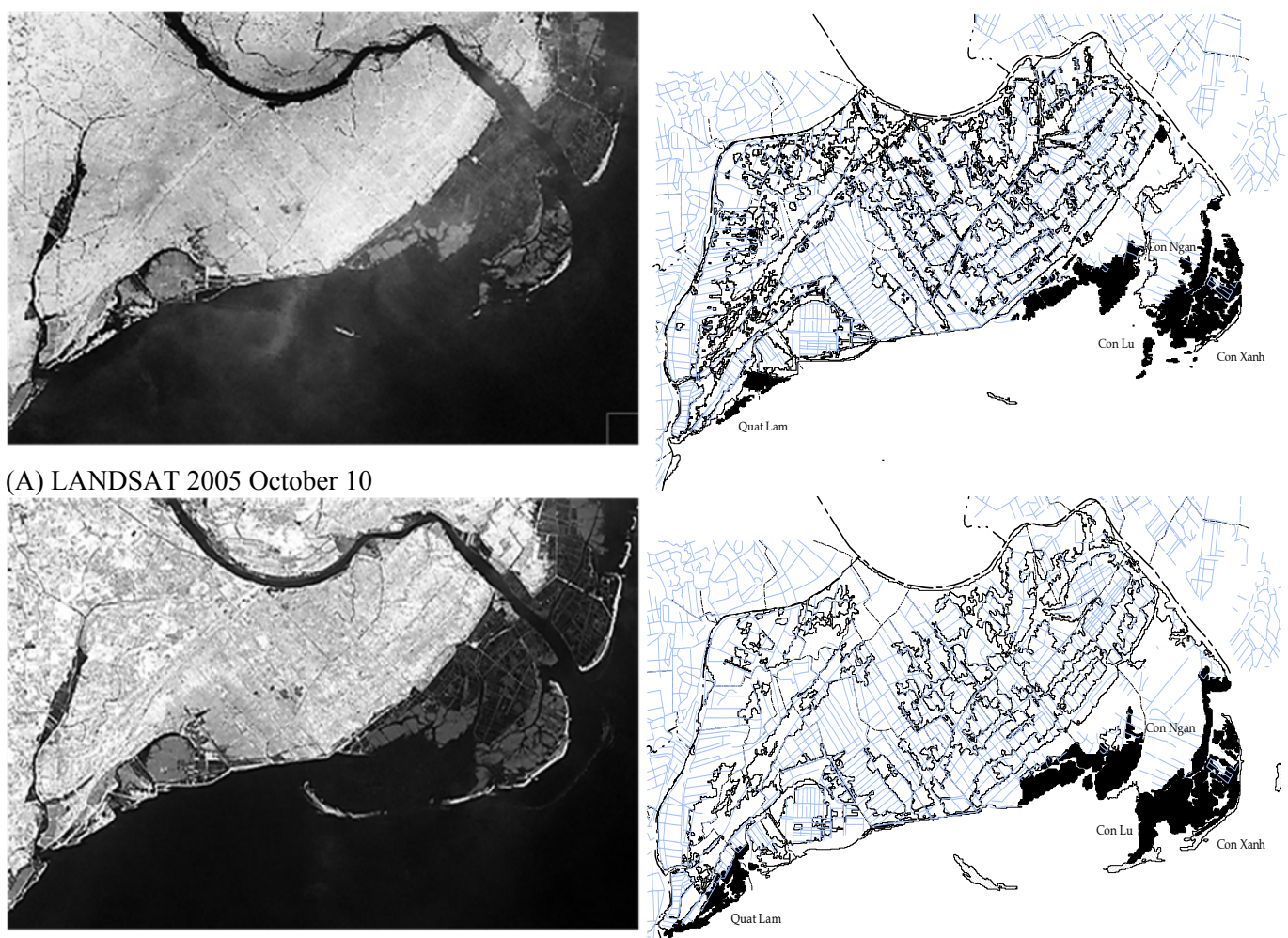

(B) LANDSAT 2010 November 9
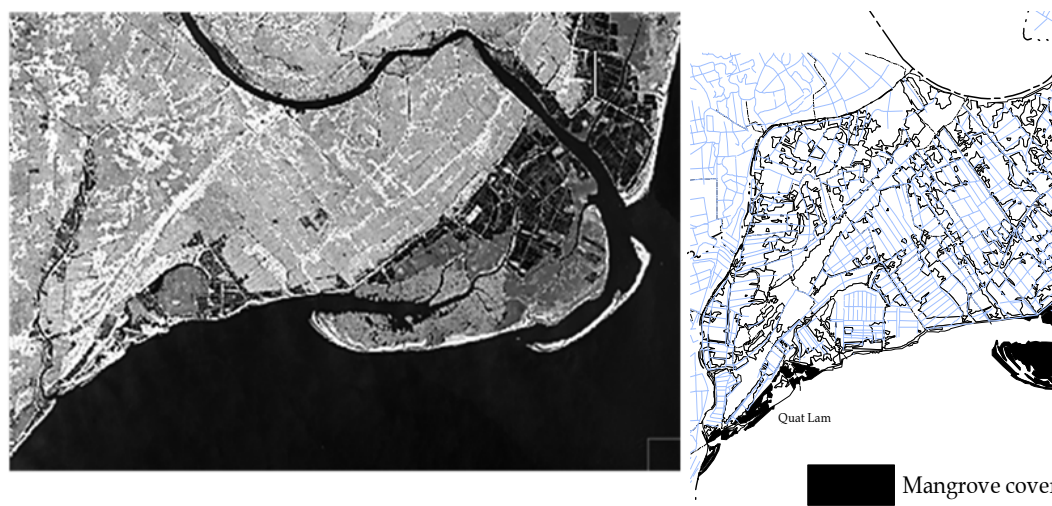

(C) LANDSAT 2014 September 25

Figure 3. LANDSAT satellite images (left) and mangrove cover maps (right) in 2005, 2010, and 2014

\subsection{Historical mangrove shoreline change}

The mangrove shoreline underwent both expansion and regression during the period 2005-2010. Figure 4 shows the baselines and the DSAS transects which were used to calculate the shoreline changes. 5 baselines were established along the Xuan Thuy NP, and the coasts of Giao Thien, Bach Long, Giao 
Phong, and Quat Lam. 272 DSAS transects have been used to calculate the shoreline dynamics. They are identified using consecutively increasing numbers from left to right. Positive values of the EPR (end point rate) indicate mangrove shoreline expansion towards the sea (increase), and negative values represent inland movements (degradation).

In 126 transects mangrove shoreline regressionwas observed, while the other 146 transects showed expansion of the mangroves. During 2005-2014, the regression rate variesbetween $0.02 \mathrm{~m} \mathrm{yr}^{-1}$ to $36.77 \mathrm{~m} \mathrm{yr}^{-1}$, with an average of $1.41 \mathrm{~m} \mathrm{yr}^{-1}$ (see the maps A, B, and $\mathrm{C}$ in the Figure 3). The rate of increase ranges between 0.03 to $49.27 \mathrm{~m} \mathrm{yr}^{-1}$, with an average of $1.26 \mathrm{~m} \mathrm{yr}^{-1}$ (see the maps B and D in the Figure 3). This figure is not in conflict with the overall increase of the mangroves which is described above. Mangrove shorelines move land inwards: new mangroves are formed inland as a result of plantation programs; whereas, damaged mangroves are merely located on tidal alluvial soils close to the sea which protects the hinterland from impacts of sea waves and storms.

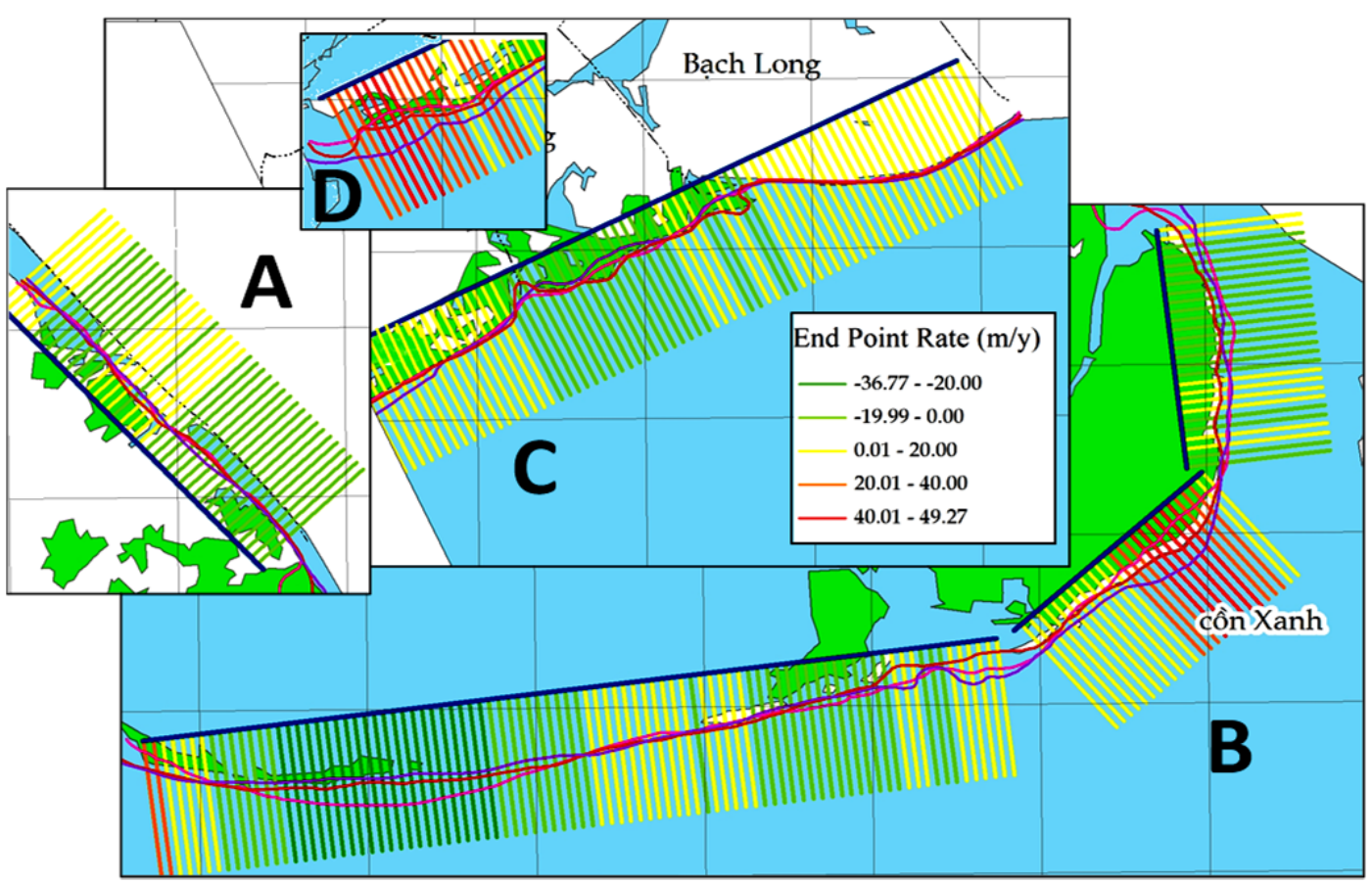

Figure 3. End Point Rate value of historical mangrove shorelines in the Giao Thuy coast during 2005-2014

Differentiating mangroves just using cover data from LANDSAT satellite images is uncertain because all mangrove patches show a homogeneous pattern and texture. As shown in figure 4, using the DSAS transect results and the derived EPR values one may disti guish 4 mangrove zones in the study area (see the figure 4):
- Mangrove zone 1 (along with the coast of the Giao Thien commune) ("A1" symbol in the map of mangrove zoning): this zone includes mangroves of the upper Ba Lat estuary. The 40 transects of this zone are consecutively numbered from 1 to 40 . These forests were lost as a result of intensive aquaculture development (mangrove MA transfer to marshland 
Nguyen An Thinh and Luc Hens/Vietnam Journal of Earth Sciences 39 (2017)

ML). EPR values range from -1.61 to $0.01 \mathrm{~m}$ yr-1.

- Mangrove zone 2 (Xuan Thuy NP) (A2): this zone includes the mangroves surrounding the lower Ba Lat estuary. Their protection status varies: In Con Lu near the core zone of the Xuan Thuy NP they are strictly protected: Con Ngan is an ecological restoration area: other mangroves are part of the beach and mining areas and are not protected. Aquaculture expanded on the bare tidal soils of the area. The mangroves near Con Xanh were the subject of natural disasters as storms, flash floods, salinization, pollution and calamities from inland industrial areas. The protected mangrove forests in this vast zone increase and expand on the bare land faster than in the three other zones. The ERP values of the 143 DSAS transects (numbered 41 to 183 ) in this zone range between 40.01 and $68.75 \mathrm{~m}$ yr- 1 in Con Lu, Con Ngan, and Con Xanh, and between 0.01 and $20.01 \mathrm{~m}$ yr-1 along the beaches of the Giao An, Giao Lac and Giao Xuan communes.
- Mangrove zone 3 (Bach Long and Giao Phong coast) (A3): this zone includes mangroves surrounding the Day estuary. Mangroves are regressing as a result of intensive agro-aquaculture development and salt production. The ERP values of the 50 DSAS transects (numbered from 184 to 235) vary between -36.77 and $-19.99 \mathrm{~m} \mathrm{yr}^{-1}$, which indicates the regression of the mangrove forest in this zone.

- Mangrove zone 4 (Quat Lam coast) (A4): this zone includes the mangroves of the Day estuary. Tourism develops in this area, while both agro-aquaculture and industry are less important and mangroves increase in this zone. A large area of bare tidal soil outside the national dike allows the expansion of the forests. The ERP values in the 36 DSAS transects (236 to 272) range between 20 to $40 \mathrm{~m}$ $\mathrm{yr}^{-1}$. This is the second fastest rate of mangrove extension along the coastline in Giao Thuy.

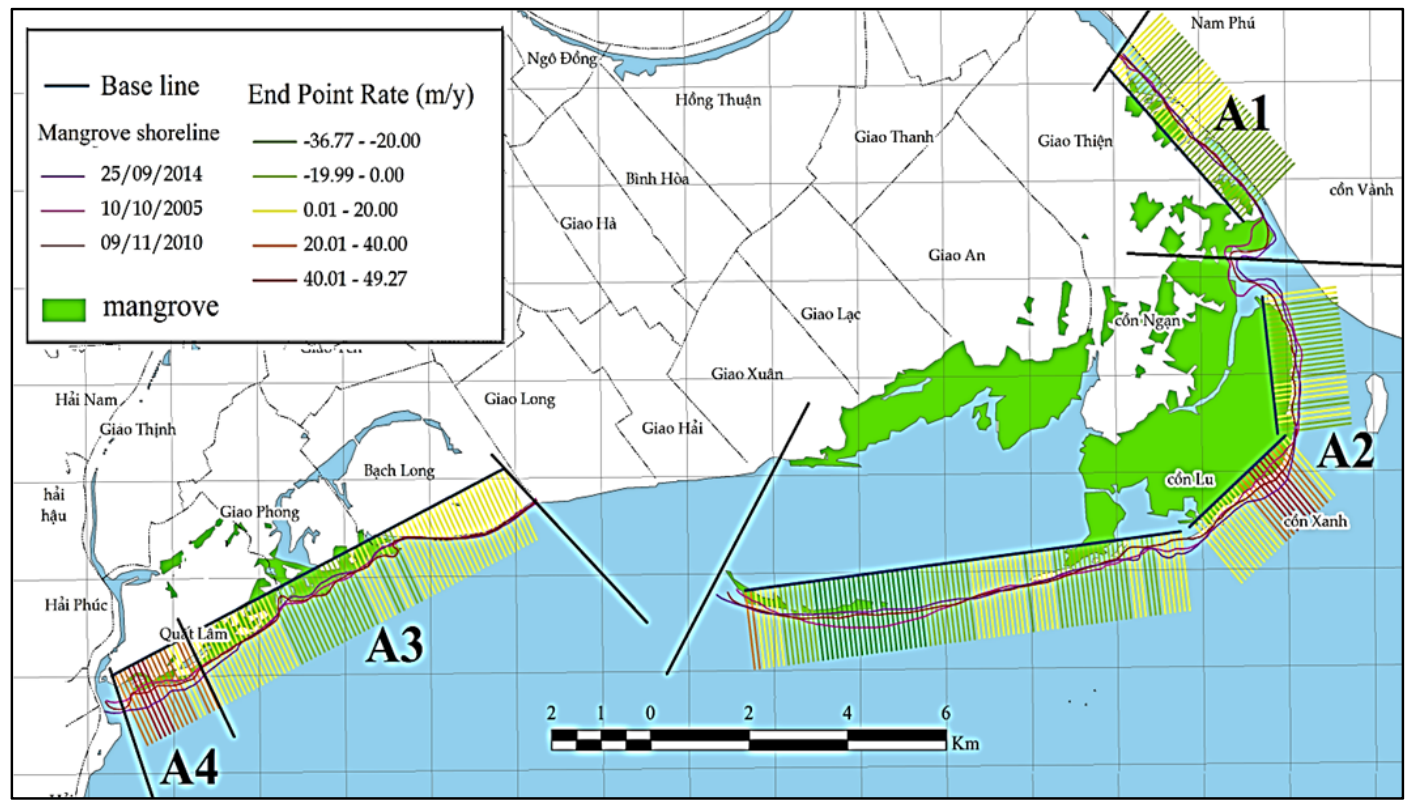

Figure 4. Mangrove zones of Giao Thuy coast 
Vietnam Journal of Earth Sciences, 39(1), 87-96

\section{Discussion and conclusion}

Overall the mangroves in the Giao Thuy district increased by 2486.96 hectares during 2005-2014. Among the 272 DSAS transects in this study, 126 showed mangrove shoreline regression, while the mangrove forests increased in the 146 other transects. The degradation rate is calculated at $1.41 \mathrm{~m} \mathrm{yr}-1$, and the growth rate is $1.26 \mathrm{~m}$ yr-1on average. The dynamic analysis of the DSAS transects using EPR-values allows defining 4 zones in the study area. Zones near the Xuan Thuy NP and along the coast of Quat Lam coast expand fastest along the coastline in Giao Thuy.

Even though other research also focused on detecting and monitoring mangrove changes in Nam Dinh province using remote sensed data (Pham et al., 2016) or based on a combination of DSAS and remote sensing (To and Thao, 2008), this is the first study using DSAS for the purpose of both mangrove shoreline change analysis and mangrove zoning. This is a methodological improvement because proved very difficult to clarify different mangrove zones by using only mangrove zone type detected on separate satellite images. The combination with DSAS statistics allows identifying indicators that discriminate between different mangrove zones. DSAS allows examining historical shorelines, which is an advantage as compared with the traditional ground survey techniques (Thieler et al., 2009). This study combines DSAS and remote sensing to describe historical mangrove shoreline changes and mangrove zoning. The results show that this combination is a practical application for decision-making on coastal management.

The main limitation of this study is in choosing the DSAS statistical change parameters defining the mangrove zones. Five main measures among which the Net Shoreline Movement (NSM), the Shoreline Change Envelope (SCE), the End Point Rate (EPR), the
Linear Regression Rate (LRR) and the Weighted Linear Regression Rate (WLR) can be used. In this study, only the End Point Rate (EPR) was calculated. However, because of the strong correlation between these values (Thieler et al., 2009), the EPR is a sensitive measure of mangrove change. It is easy to understand as it calculates the shoreline position over different time periods.

Socio-economic development, but also environmental factors as global climate change explain the changes and make further studies imperative. Not only the rate of change should be quantified, but also the drivers of the changes should be identified in more detail. Historical mangrove shoreline change should be considered as a parameter to monitor changes in coastal environments as indicators of global warming, climate change, storm effects, sea level change, pollution, and sedimentation rates.

\section{References}

Alongi, D.M., 2008. Mangrove forests: Resilience, protection from tsunamis, and responses to global climate change. Estuarine, Coastal and Shelf Science, 76(1), 1-13.

Cohen, M.C.L., Lara R.J., 2003. Temporal changes of mangrove vegetation boundaries in Amazonia: Application of GIS and remote sensing techniques. Wetland Ecology Management 11, 223-231.

Ellison, J., 2000. How South Pacific mangroves may respond to predicted climate change and sea level rise. In: Gillespie A. and Burns W. (Eds.). Climate change in the South Pacific: Impacts and responses in Australia, New Zealand, and small islands states. Dordrecht, Netherlands: Kluwer Academic Publishers (Chapter 15), 289-301.

Hegde, A.V., Akshaya B.J., 2015. Shoreline transformation study of Karnataka Coast: Geospatial Approach. Aquatic Procedia 4, 151-156.

Lewis, R.R., 2005. Ecological engineering for successful management and restoration of mangrove forests. Ecological Engineering, 24(4SI), 403-418.

Moussaid, J., Fora A.A., Zourarah B., Maanan M., Maanan M., 2015. Using automatic computation to 
Nguyen An Thinh and Luc Hens/Vietnam Journal of Earth Sciences 39 (2017)

analyze the rate of shoreline change on the Kenitra coast, Morocco.Ocean Engineering, 102(1), 71-77.

Nguyen Hai Hoa, McAlpine C., Pullar D., Leisz S.J., Galina G., 2015. Drivers of coastal shoreline change: case study of Hon Dat coast, Kien Giang, Vietnam. Environmental Management, 55(5), 1093-1108.

Oyedotun, T.D.T., 2014. Shoreline Geometry: DSAS as a tool for historical trend analysis. Geomorphological Techniques, Chapter 3(2.2), British Society for Geomorphology, 1-12.

Pham Quang Son, Nguyen Duc Anh, 2016. Evolution of the coastal zone in Hai Hau district (Nam Dinh province) and nearest region over the last 100 years based on analysis topographic maps and multitemporal remote sensing data. Vietnam Journal of Earth Sciences, 38(1), 118-130 (in Vietnamese).

Rebelo, L.M., Finlayson C.M., Nagabhatla N., 2009. Remote sensing and GIS for wetland inventory, mapping and change analysis. Environmental Management, 90, 2144-2153.

Sathirathai, S., Barbier E.B., 2001. Valuing mangrove conservation in southern Thailand. Contemporary
Economic Policy, 19(2), 109-122.

Sheik, M., Chandrasekar, 2011. A shoreline change analysis along the coast between Kanyakumari and Tuticorin, India, using digital shoreline analysis system. Geo-spatial Information Science, 14(4), 282.

Thieler, E.R., Himmelstoss E.A., Zichichi J.L., Ergul A., 2009. Digital Shoreline Analysis System (DSAS) version 4.0 - An ArcGIS extension for calculating shoreline change.U.S. Geological Survey Open-File Report 2008-1278.

Dang Van To, Phan Thi Phuong Thao, 2008. A shoreline analysis using DSAS in Nam Dinh coastal area. GeoInformatics, 4(1), 37-42.

Tran Thi V., Xuan A Tien Thi., Phan Nguyen Hong, Dahdouh-Guebas F., Koedam N. , 2014. Application of remote sensing and GIS for detection of longterm mangrove shoreline changes in Mui Ca Mau, Vietnam. Biogeosciences ,11, 3781-3795.

$\mathrm{Vu}$ Van Loi, 2016. Sedimentary facies and engineering geological characteristics of Holocene deposits in the coastal area of Tien Lang district, Hai Phong city. Vietnam Journal of Earth Sciences, 38(1), 108-117. 